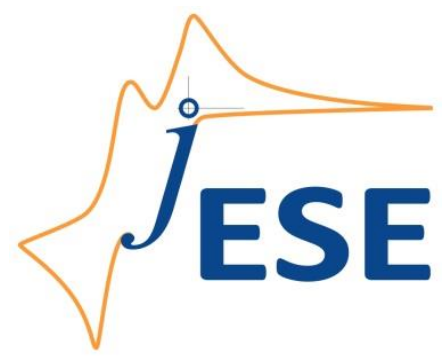

Open Access : : ISSN 1847-9286

www.jESE-online.org

Original scientific paper

\title{
The interactions between lipase and pyridinium ligands investigated by electrochemical and spectrophotometric methods
}

\author{
Simona Patriche, Elena Georgiana Lupu, Andreea Cârâc*, Rodica Mihaela Dinică, \\ Geta Cârâc ${ }^{\bowtie}$ \\ Department of Chemistry, Physics and Environment, Faculty of Sciences and Environment, \\ "Dunărea de Jos" University of Galati, 111 Domneasca Street, 800201 Galati, Romania \\ *Department of Fundamental Science, Faculty of Pharmacy, "Carol Davila" University of Medicine \\ and Pharmacy of Bucharest, 6 Train Vuia Street, 020956 Bucharest, Romania
}

${ }^{\otimes}$ Corresponding Author: geta.carac@ugal.ro; Tel.: +40 745358 371; Fax: + 40236461353

Received: September 30, 2015; Accepted: February 10, 2016

\begin{abstract}
The interaction between pyridinium ligands derived from 4, $4^{\prime}$-bipyridine ( $N, N^{\prime}$-bis (p-bromophenacyl)-4,4'-bipyridinium dibromide - Lr) and ( $N, N^{\prime}$-bis(p-bromophenacyl)-1,2-bis (4-pyridyl) ethane dibromide - Lm) with lipase enzyme was evaluated. The stability of the pyridinium ligands, having an essential role in biological systems, in $0.1 \mathrm{M} \mathrm{KNO}_{3}$ as supporting electrolyte is influenced by the lipase concentration added. The $\mathrm{pH}$ and conductometry measurements in aqueous solution suggest a rapid ionic exchange process. The behavior of pyridinium ligands in the presence of lipase is investigated by cyclic voltammetry and UV/Vis spectroscopy, which indicated bindings and changes from the interaction between them. The voltammograms recorded on the glassy carbon electrode showed a more intense electronic transfer for the Lr interaction with lipase compared to $L m$, which is due to the absence of mobile ethylene groups from Lr structure.
\end{abstract}

\section{Keywords}

Enzyme; Pyridine; Cyclic voltammetry; Morphology; Physicochemical properties

\section{Introduction}

Pyridinium ligands are very interesting compounds with many applications and they have significant antimicrobial properties, being involved in the inhibition of microorganism growth (bacteria and fungus) [1,2]. Also, the compounds are used as electronic transporters, biological 
redox indicators [3], model systems in photosynthesis [4], cardiovascular, hypotensive [5] and neuromuscular agents [6], catalysts [7], acylation agents and ionic liquids [8].

Pyridinium ligands have an essential role in biological systems and could be involved in cycloaddition reactions with different dipolarophiles (ethyl propiolate), in order to obtain the indolizine core using enzymes as biocatalysts. Dipolarophiles such as ethyl propiolate are important precursors used to obtain indolizines through cycloaddition reactions of quaternary pyridinium ligands with activated alkynes.Phenacyl bromide is also an important precursor involved in the biocatalytic process with lipase [9]. N-heterocyclic quaternary ligands were designed as precursors for fluorescent indolizine synthesis [10].

Lipases are biocatalysts with a broad application in various industries, such as chemical [11-12], pharmaceutical $[13,14]$, cosmetics [15] or agrochemical sectors $[16,17]$. They have a significant capacity to catalyze the conversion of various compounds (enzymatic substrate) to different products. These enzymes belong to the hydrolases group (hydrolytic enzymes), having the ability of acting at the interface between the aqueous and organic phase $[18,19]$. Contrary to other hydrolytic enzymes that act invariably on monomolecular substrates, lipases exhibit a growth in activity at the water-lipid interface [20].

Commercial lipases could also be used in biocatalytic reactions to obtain indolizines [9]. Due to their eco-friendly and recyclable properties, lipases are involved in the synthesis of tricyanovinylated compounds [21] and in the design of mesoporous materials [22], green polymers [23] and bioelectrodes used to detect triglycerides in human serum [24]. There are many methods, both analytical and electrochemical, to detect lipase activity. Selective review about lipase activity were recently reported in the literature $[19,25]$. Nevertheless, there are limited studies involving the interaction of lipase with the pyridinium salts. The aim of our study is to detect whether the interaction between lipase and pyridinium ligands generates redox properties, in order to predict a possible biocatalytic mechanism. As such, the lipase interaction of various concentrations with pyridinium ligands derived from 4,4'-bipyridine was investigated by cyclic voltammetry and spectrophotometryic method.

The pyridinium ligands studied are viologens $[26,28]$ with interesting spectrophotometric and electrochemical properties [27]. It is the first time when the interaction of such compounds and lipase is investigated using electrochemical methods, and the biocatalytic properties derived from these interactions could be further used to understand their use in biocatalysis leading to the indolizine ring.

\section{Experimental}

The synthesis of two pyridinium ligands was performed by reacting the heterocycles 4,4'-pyridyl and 1,2-bis(4-pyridyl)ethane with phenacyl bromide (as precursor) according to the method already reported in the literature $[26,28]$. The synthesized ligands are $N, N^{\prime}$-bis $(p$-bromophenacyl)4,4'-bipyridinium dibromide (rigid ligand, Lr) and N,N'-bis( $p$-bromophenacyl)-1,2-bis(4-pyridyl)ethane dibromide (mobile ligand, Lm).

All chemical reagents were obtained from commercial sources of analytical grade (Merck) and used without further purification.

Solutions of $0.1 \mathrm{mM}$ of each pyridinium ligand, dissolved in $0.1 \mathrm{M} \mathrm{KNO}_{3}$ as electrolyte support were prepared. Aqueous solutions were prepared with double deionized water having a conductivity of $1.6 \mu \mathrm{S} \mathrm{cm}^{-1}$ (Milli-Q Millipore Losheim France). Variable concentrations of lipase (0.05, 0.25 and $0.50 \mathrm{mg} \mathrm{mL}^{-1}$ ) were added to the pyridinium ligands solutions. Commercial lipase enzyme 
(Candida antartica) was stored at $-5{ }^{\circ} \mathrm{C}$. Data were collected from fresh-made ligand solutions (lower acid $\mathrm{pH}$ ) and during a certain period of time (1-14 days). The stability of the aqueous soluteons with and without lipase at room temperature $\left(20 \pm 1^{\circ} \mathrm{C}\right)$ was evaluated by physicochemical measurements.

The values of $\mathrm{pH}$ and conductivity were measured with a Consort C862 multiparameter analyzer. The spectrophotometric analysis from 200 to $800 \mathrm{~nm}$ using quartz cuvettes was performed. UV-Visible absorption spectra were recorded by a UV-VIS T90+ spectrophotometer (Varian, Australia) with $1 \mathrm{~cm}$ path length. The redox properties of the interaction between lipase and ligands were investigated by cyclic voltammetry. The measurements were performed using the Bio-logic SP50 equipment with a carbon electrode immersed in the ligand solutions with and without enzyme. The voltammetric curves were recorded to show the electrochemical responses of the reaction system in the potential range from a negative direction of $E=-1.0$ to $1.0 \mathrm{~V} \mathrm{vs}$. $\mathrm{Ag} / \mathrm{AgCl}$, at various scan rates between $0.50-0.02 \mathrm{~V} \mathrm{~s}^{-1}$. An electrochemical cell of $10 \mathrm{~mL}$ capacity with three electrodes was used (carbon working electrode $-1.6 \mathrm{~mm}^{2}, \mathrm{Ag} / \mathrm{AgCl}$ sat. reference electrode $\left(E_{\mathrm{Ag} / \mathrm{AgCl} \text { sat. }}=0.197 \mathrm{~V}\right.$ vs. $\left.\mathrm{EHN}\right)$, Pt wire counter electrode). All measurements were performed at $20 \pm 1{ }^{\circ} \mathrm{C}$ without deoxygenating the solutions. However, to evaluate all the changes before an electrochemical measurement, several solutions were deoxygenated by bubbling with highly purified nitrogen for 5 minutes. The enzyme interaction with the ligand solutions was also investigated at $40{ }^{\circ} \mathrm{C}$. The free redox potential (open circuit potential - OCP) and cyclic voltammetry (CV) measurements were repeated three times to mark the significant changes that might appear in the solutions. The interaction of the enzyme with the precursor (phenacyl bromide) and the dipolarophile ethyl propiolate was also electrochemically investigated.

The morphology of the lipase after interaction with ligands was characterized by scanning electron microscopy (SEM) using Quanta 200 equipment. After filtering the solutions, the lipase was dried in air at room temperature and placed on carbon-coated copper grid to perform the SEM analysis and energy dispersive X-ray spectroscopy (EDX).

\section{Results and discussion}

The stability of pyridinium ligands in the absence and the presence of lipase

The lipase enzyme interaction with the rigid ligand ( $L r)$ and mobile ligand $(L m)$ through the evaluation of physico-chemical properties $(\mathrm{pH}$, conductivity and spectrophotometric measurements) was investigated during a certain period of time (1-14 days) at room temperature.

$\operatorname{Lr}(0.1 \mathrm{mM})$ has shown a $\mathrm{pH}$ of 6.5 in the fresh-made aqueous solution and remained stable after 2 days as over 14 days. By adding a small amount of lipase $\left(0.05 \mathrm{mg} \mathrm{mL}^{-1}\right)$, no essential modification in the $\mathrm{pH}$ of $\mathrm{Lr}$ electrolyte $\left(0.1 \mathrm{M} \mathrm{KNO}_{3}\right)$ was observed after 2 days from the initial contact with the enzyme. With the increase of the lipase amount added in the solution, the $\mathrm{pH}$ decreased slowly in time. After 7 days the system with $0.5 \mathrm{mg} \mathrm{mL}^{-1}$ lipase showed a decrease with one unit of $\mathrm{pH}$ compared to $\mathrm{Lr}$ without enzyme (Figure 1). Usually, after 14 days the $\mathrm{pH}$ of all solutions turned to the initial $\mathrm{pH}$ as an effect of the potential equilibrium reached in solutions.

$\mathrm{Lm}$, initially characterized also by a weak acidic $\mathrm{pH}$, remained stable after 2 days with an increase of $0.4 \mathrm{pH}$ units over 14 days. At the same time, the presence of lipase induced significant changes in the $\mathrm{pH}$ of the Lm solution compared to $\mathrm{Lr}$, mainly at a higher amount of enzyme added $\left(0.5 \mathrm{mg} \mathrm{mL}^{-1}\right)$, a neutral to weak alkaline $\mathrm{pH}$ being recorded (Figure 1). As the time passed, an optimum operating $\mathrm{pH}$ of lipase (neutral $\mathrm{pH}$ ) was achieved and an increase of $\mathrm{OH}^{-}$ions was observed and the enzyme became more active at $\mathrm{pH}$ more than 7.4 , as was reported in the literature [29]. 

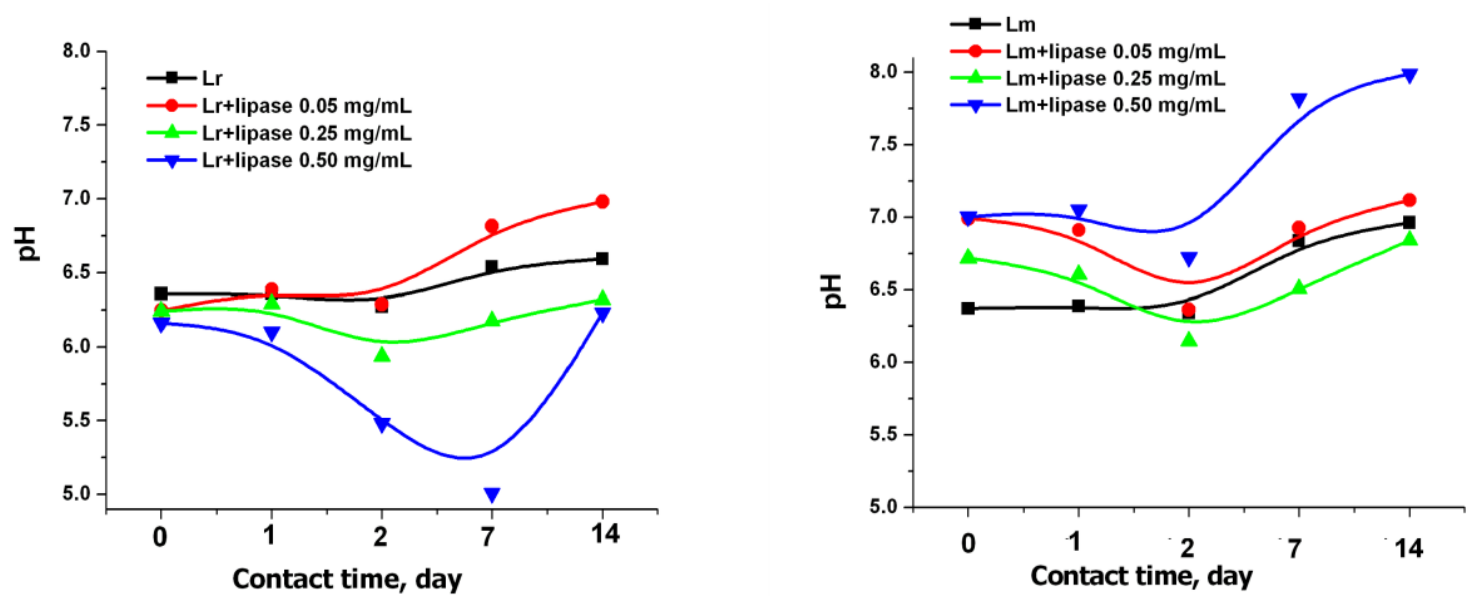

Figure 1. Time evolution of $\mathrm{pH}$ of the solutions containing the rigid and mobile ligand (Lr and Lm) with and without lipase

Aqueous solutions of the ligands $(0.1 \mathrm{mM})$ electrolyte without lipase presented conductivities of $12-13 \mathrm{mS} \mathrm{cm}$, which confirms an intense dissociation process of zwitterion structures according to reference [30]. In all systems, a constant decrease of conductivity in time was recorded with $2 \mathrm{mS} \mathrm{cm}^{-1}$ after the first and second day, and after that it remained almost constant (Figure 2). However, a more significant variation of conductivity was obtained in the case of $\mathrm{Lm}$ in the presence of lipase. Thus, for 0.05 and $0.25 \mathrm{mg} \mathrm{mL}^{-1}$ of lipase after 7 days, a decrease to half of conductivity was reached. The fact that the dissociation of ions decreases suggests a binding between the enzyme and pyridinium ligands according to reference [31].
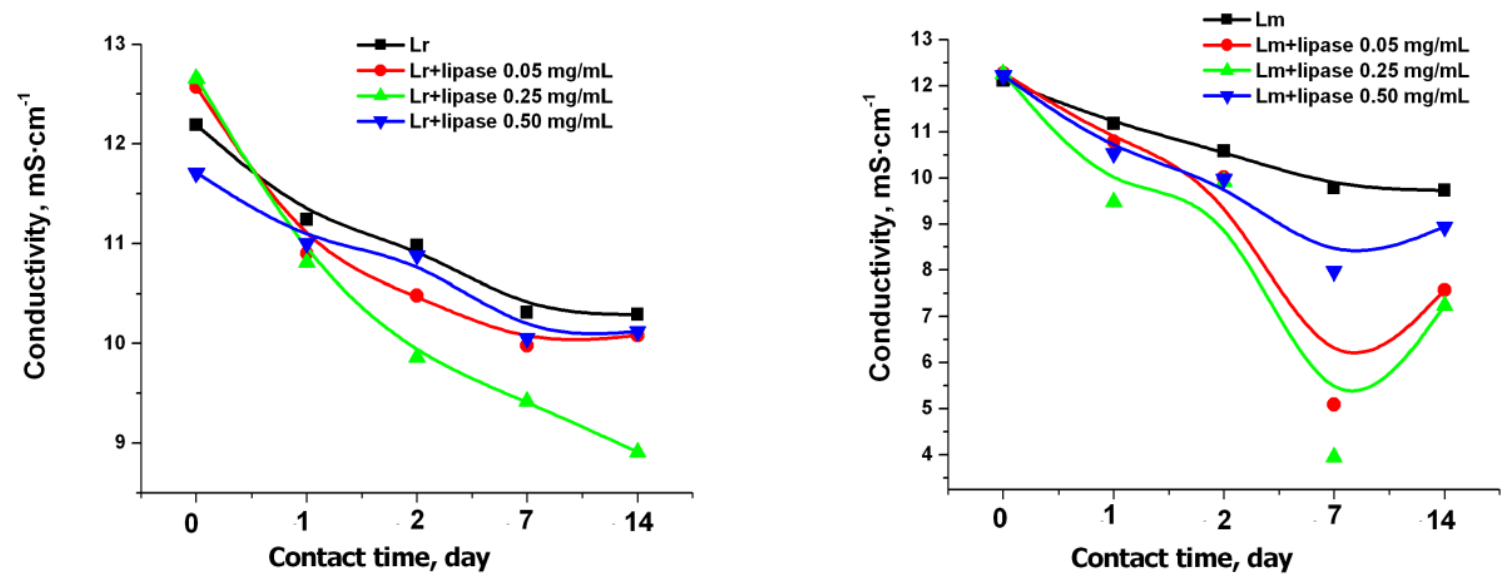

Figure 2. Time evolution of conductivity of the solutions containing the rigid and mobile ligand (Lr and $L m$ ) with and without lipase

Temperature effect on pyridinium ligands in the absence and presence of lipase

An enzymatic reaction is affected by temperature and many studies showed that the optimum activity of the enzyme occurs at a temperature between $35-40{ }^{\circ} \mathrm{C}[22,32]$. In the case of lipase, the optimal temperature was reported at $37-40{ }^{\circ} \mathrm{C}$ [33]. The ligands in $0.1 \mathrm{M} \mathrm{KNO}_{3}$ electrolyte in contact with different lipase amounts were analysed at $40{ }^{\circ} \mathrm{C}$ (keeping the temperature constant) without stirring and emulsifying agent, to observe changes which occur in the lipase interaction. With the temperature increase, for both $\mathrm{Lr}$ and $\mathrm{Lm}$, changes of $\mathrm{pH}$ were recorded, showing an augmentation of the obtained values (Figure 3). $\mathrm{Lr}$ showed the decrease of $\mathrm{pH}$ in the presence of enzyme. On the other hand, the $\mathrm{pH}$ of $\mathrm{Lm}$ increased to a more alkaline one upon the interaction with lipase, varying between $6.8\left(0.05 \mathrm{mg} \mathrm{mL}^{-1}\right.$ - lower enzyme concentration) to $8.2\left(0.50 \mathrm{mg} \mathrm{mL}^{-1}\right.$ - higher enzyme concentration). 
The conductivity was drastically reduced at $40{ }^{\circ} \mathrm{C}$, being situated in this case in the $\mu \mathrm{S} \mathrm{cm}^{-1}$ range compared to the systems' electrolyte, which at $20^{\circ} \mathrm{C}$ was $10^{3}$ times lower. These results indicate the existence of an interaction between pyridinium ligands and lipase. The ionic dissociation of the ligands electrolyte solutions without enzyme indicates a difference of approx. $200 \mu \mathrm{S} \mathrm{cm}^{-1}$ more for $\mathrm{Lm}$ compared to $\mathrm{Lr}$. In the presence of lipase different behaviour of the dissociation process was observed. $\mathrm{Lr}$ from fresh-made solution without lipase indicated a conductivity reduced in half $\left(114 \mu \mathrm{Sm}^{-1}\right)$ in contact with $0.05 \mathrm{mg} \mathrm{mL}^{-1}$ lipase and a slight increase of up to $135 \mu \mathrm{S} \mathrm{cm}^{-1}$ for $0.50 \mathrm{mg} \mathrm{mL}^{-1}$ lipase (Figure 3). At the same time, Lm showed in the presence of $0.05 \mathrm{mg} \mathrm{mL}^{-1}$ lipase a decrease of conductivity of $145 \mu \mathrm{S} \mathrm{cm}^{-1}$ from fresh electrolyte without lipase $\left(343 \mu \mathrm{S} \mathrm{cm}^{-1}\right.$ ) and a slight increase of up to $317 \mu \mathrm{S} \mathrm{cm}^{-1}$ for more lipase added. Therefore, an inhibition of ionic dissociations occurred by raising the temperature of both ligands in the absence and presence of lipase, depending on the enzyme amount.
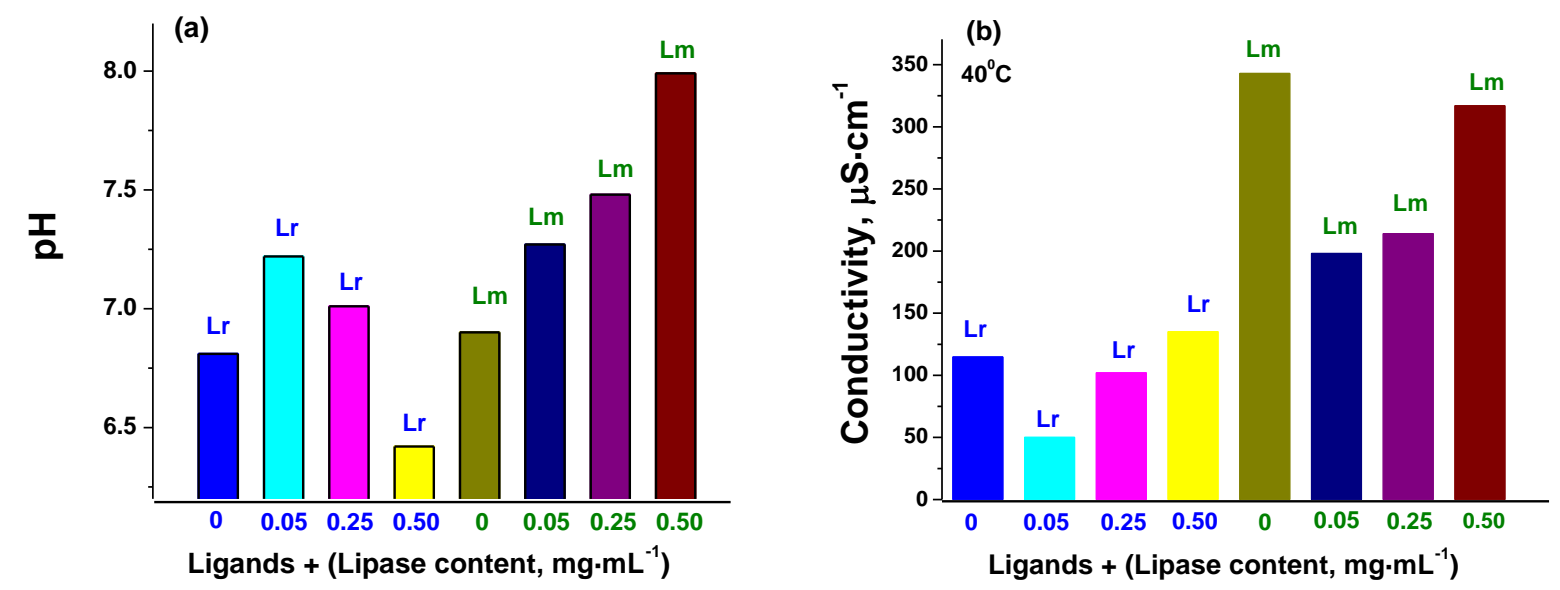

Figure 3. The effect of temperature at $40^{\circ} \mathrm{C}$ in the evolution of $\mathrm{pH}$ and conductivity of the pyridinium ligands in the presence of lipase

UV-Vis spectrophotometric studies of the interaction with lipase

UV-Vis spectra in the scanning range of 200-700 $\mathrm{nm}$ for all aqueous solutions with and without lipase were recorded. The absorption peak for $L r$ and $L m$ is at $264 \mathrm{~nm}$ (UV), the maximum wavelength $\left(\lambda_{\max }\right)$ being caused by the $\pi \rightarrow \pi^{*}$ electron transition of benzene ring, which is in accordance with references $[1,26]$. The absorbance indicates a shift for both ligands aqueous solutions when in contact with lipase. The obvious variation of the UV-Vis data is caused by the influence of ligands' structure and lipase complex structure, as well as the interaction between them. The highest absorbance was obtained for Lr compared to Lm in the presence of lipase, obtaining an interaction between them. The absorbance of lipase and ligands, respectively is not equal to the sum of the absorbance, indicating that lipase could interact with the ligands at room temperature according to reference [34].

Figure 4a shows the variations of the absorbance from UV-Vis spectra of ligand solutions at room temperature when different quantities of lipase were added. When the enzyme was added, the absorption peak of pyridinium ligands decreased without alteration of the maximum absorption wavelength.

The interaction of lipase with the ligands' structure has induced the diminution of the absorbance, more obvious for $\mathrm{Lm}$ than $\mathrm{Lr}$, so the mobile ligand is more favourable for these interactions. The higher lipase concentration generated the lower absorbance, which suggests that a binding reaction had taken place between the enzyme and ligands. The lowest absorbance was attained for the lipase concentration of $0.5 \mathrm{mg} \mathrm{mL}^{-1}$, as a consequence of the diminution of the major 
component in the ligands electrolyte [35]. The same downward trend of the absorbance was maintained in the interaction of the lipase for both pyridinium ligands in time over 14 days (Figure 4a).
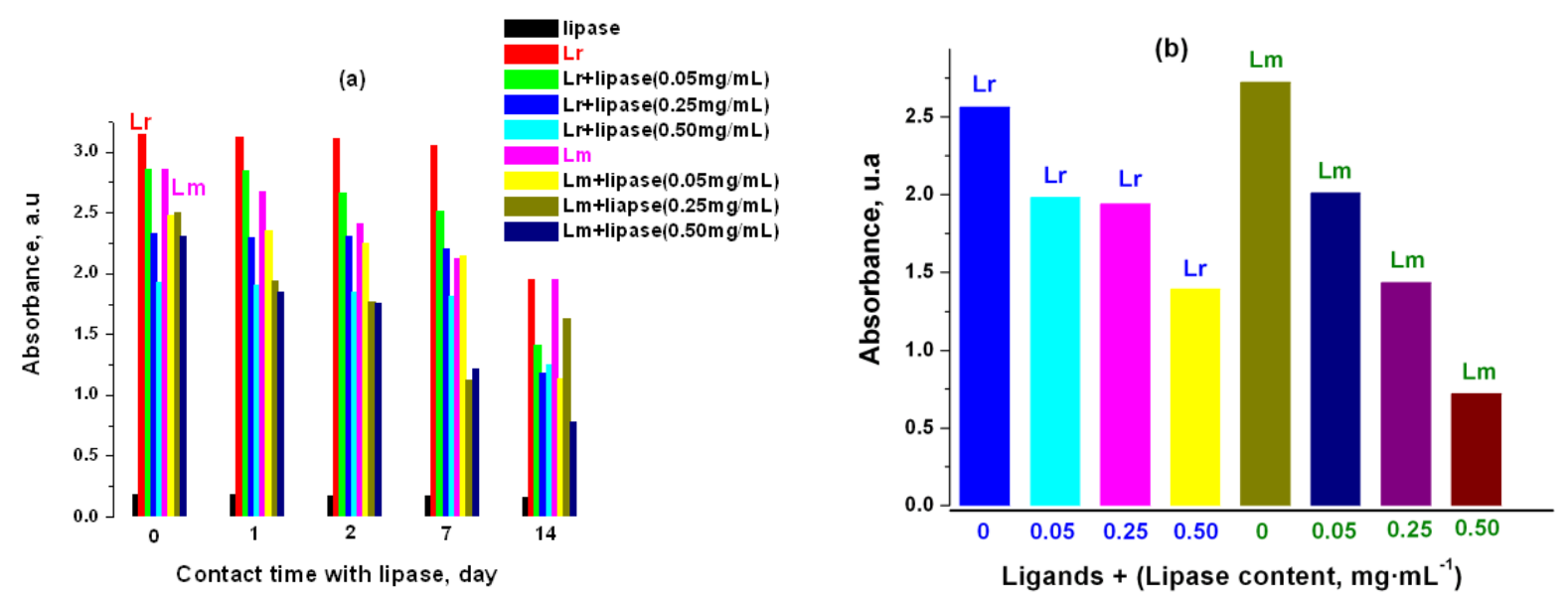

Figure 4. Time evolution of the absorbance of pyridinium ligands with and without lipase and at room temperature (a) and the effect of temperature of $40^{\circ} \mathrm{C}(\boldsymbol{b})$

The lipase interaction with ligands was also evaluated at $40{ }^{\circ} \mathrm{C}$ by the absorbance peak evolution from the UV-Vis spectra of fresh-made aqueous solutions (Figure 4b). In both systems a decrease of absorbance was observed, as an effect of the enzyme activity increase at that temperature, compared to the behaviour at room temperature. With the increase of the lipase concentration, a hypochromic effect of the absorption peak was observed. The absorbance decrease showed an intensive lipase binding interaction with the ligands molecule, more clearly for $\mathrm{Lm}$, having an ethylene group in its structure $[35,36]$.

\section{Electrochemical studies}

The ligands electrolyte with and without lipase, initial and after 1, 2, 7 and 14 days respectively, kept at constant temperature $\left(20^{\circ} \mathrm{C}\right)$ were analyzed by electrochemical measurements.

OCP measurements of the $\mathrm{Lr}$ electrolyte without enzyme showed a potential ranging from $0.034 \mathrm{~V}$ to $0.045 \mathrm{~V} v$ s. $\mathrm{Ag} / \mathrm{AgCl}$ to $2000 \mathrm{~s}$ and for $\mathrm{Lm}$ between $0.052-0.056 \mathrm{~V} v \mathrm{vs} . \mathrm{Ag} / \mathrm{AgCl}$, as effect of the zwitterionic ligands' structure (results not shown).

The influence of the ionic interaction between $\mathrm{Lr}$ and lipase in the aq. electrolyte on carbon electrode was observed by sifting from the beginning of the OCP values (results not shown). In time, by adding more lipase, the OCP values increase (to the positive region) as an effect of the formation of an electro-active complex with changes of the electrochemical parameters. Smaller lipase concentration has influence on the OCP values recorded, so, for $0.25 \mathrm{mg} \mathrm{mL}^{-1}$ lipase $\Delta E$ was $12 \mathrm{mV}$ and respectively for $0.05 \mathrm{mg} \mathrm{mL}^{-1}$ lipase the $\Delta \mathrm{E}$ was $5 \mathrm{mV}$ (results not shown). The increase of OCP values until $2000 \mathrm{~s}$ up to $\Delta E$ of $30 \mathrm{mV}$ for $0.50 \mathrm{mg} \mathrm{mL}^{-1}$ lipase confirms a rapid initiation of the enzyme's activity and an electronic exchange mechanism. The same trend is observed on OCP values of $\mathrm{Lr}$ in the deoxygenated aq. electrolyte in presence of lipase; $\Delta E$ increase with $10 \mathrm{mV}$ for all analysed lipase concentrations (results not shown).

In case of Lm which has an ethylenic group, the interaction with lipase is indicated by the begging a decrease (to the negative region) of OCP values with a $\triangle E$ of $20 \mathrm{mV}$ in comparison with $\mathrm{Lm}$ without enzyme. A shift to the positive and negative region of OCP values is an indication of an active surface of ligands. In time, essential modifications of OCP values depending on the lipase added were not recorded (results not shown). 
Cyclic voltammetry measurements were performed as a useful electroanalytical method to characterize the reduction ability and electrochemical behaviour of pyridinium ligands in the lipase biocatalyzed cycloaddition $[37,38]$. Oxidation processes (anodic reactions) manifest themselves in positive current peaks, and reduction processes (cathodic reactions) in negative peaks and these are useful in understanding the mechanism of the reaction [39].

The cyclic voltammetric curves were recorded to show the electrochemical responses in the potential range between $E= \pm 1 \mathrm{~V} v$ s. $\mathrm{Ag} / \mathrm{AgCl}$. The lipase content in the ligands' electrolyte has substantial effects on the electrochemical properties as voltammetric response.

\section{Effect of the lipase concentration}

Figure 5 shows the cyclic voltammograms of the ligands` electrolyte in the absence and presence of different amounts of lipase. In the absence of enzyme an anodic current peak $I_{a}$ of $0.24 \mu \mathrm{A}$ (at $+0.7 \mathrm{~V}$ for $0.1 \mathrm{~V} \mathrm{~s}^{-1}$ ) for $L r$ is recorded in comparison with $\mathrm{Lm}$ which presents lower anodic current, of $0.14 \mu \mathrm{A}$ (at $+0.7 \mathrm{~V}$ ). An explanation is that $\mathrm{Lr}$ is more electrochemical active compared to $\mathrm{Lm}$, because of the structural differences, $\mathrm{Lm}$ having a mobile ethylenic group in its structure $[9,26,27]$.
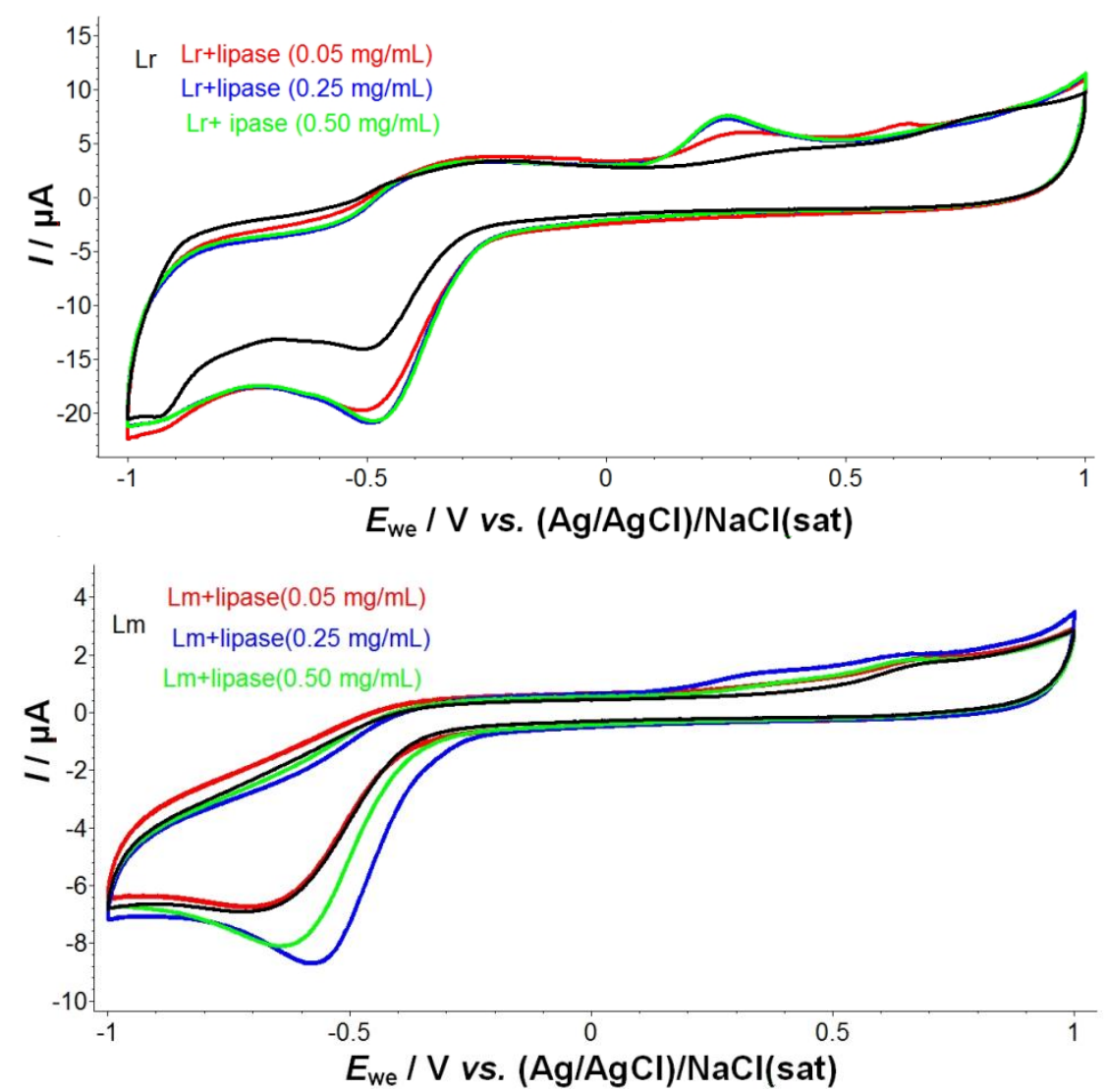

Figure 5. $C V$ s recorded of $L r$ and $L m$ electrolyte in the presence of different concentrations of lipase. $\mathrm{E}_{\text {we }} / \mathrm{V}$ vs. $(\mathrm{Ag} / \mathrm{AgCl}), 0.5 \mathrm{~V} \mathrm{~s}^{-1}$ for $\mathrm{Lr}$ and $0.1 \mathrm{~V} \mathrm{~s}^{-1}$ for $\mathrm{Lm}$

The anodic current peak increases with $0.25 \mu \mathrm{A}$ and a new current peak appeared for $\mathrm{Lr}$ electrolyte in the presence of $0.05 \mathrm{mg} \mathrm{mL}^{-1}$ lipase added, in comparison with $\mathrm{Lr}$ without enzyme. When more lipase was added to the $\mathrm{Lr}$ electrolyte, a relatively distinct anodic current peak (peak a) appears at a potential of $0.25 \mathrm{~V}$ vs. $\mathrm{Ag} / \mathrm{AgCl}$. The increase with $1.50 \mu \mathrm{A}$ was observed when $0.5 \mathrm{mg} \mathrm{mL}^{-1}$ lipase was added and the $\mathrm{Lr}$ molecule readily undergoes electrooxidation. When the concentration of enzyme was gradually increased from 0.05 to $0.50 \mathrm{mg} \mathrm{mL}^{-1}$ there was a 
gradual increase in the current peak response and this response was finally saturated for a $0.25 \mathrm{mg} \mathrm{mL}^{-1}$ of lipase $\left(I_{\mathrm{a}}=1.76 \mu \mathrm{A}\right)$ and remained almost constant (Figure 5).

The interaction of $\mathrm{Lm}$ with lipase has shown a constant reduced anodic current peak between $0.8 \mu \mathrm{A}$ to $1.5 \mu \mathrm{A}$ over the applied potential without any distinct peak.

Both ligands present a reductive peak, around at $-0.45 \mathrm{~V} v \mathrm{v}$. $\mathrm{Ag} / \mathrm{AgCl}$ for $\mathrm{Lr}$ and around at $-0.7 \mathrm{~V}$ for $\mathrm{Lm}$, which indicated that the electrochemical behaviour on carbon electrode is reversible. Anyway, the reductive peak current of $L m$ is reduced in half compared to $L r$ (e.g. at scan rate of $0.5 \mathrm{~V} \mathrm{~s}^{-1} I_{\mathrm{c}}=-14.5 \mu \mathrm{A}$ for $\mathrm{Lr}$ and respectively $I_{\mathrm{c}}=-8.5 \mu \mathrm{A}$ for $\mathrm{Lm}$ is shown). On the lipase adding, the reductive current peak of $L r$ decreased without the shift of the potential. At the same time the interaction of $\mathrm{Lm}$ with lipase has shown a decrease of the reductive peak and a slightly shift of the potential to a more positive direction (from -0.7 to $-0.5 \mathrm{~V}$ ) because is not consistent with competetive adsorption.

The concentration dependence on the peak current shows a sensitive linear correlation when different amounts of lipase were added $\left(0.05\right.$ to $\left.0.50 \mathrm{mg} \mathrm{mL}^{-1}\right)$. The increase of the oxidation current in the presence of lipase is attributed to the weak formation of the Lr cation on carbon electrode. The results indicate that a binding reaction has occurred in the solutions and the electrode process was reversible. The anodic peak current of ligands did not disappear completely with the increase of the concentration of lipase, which was not the character of competitive adsorption. The reason for the decrease of the reductive peak current after the interaction of the ligand with lipase may be the competitive adsorption between the $L r$ and lipase on the carbon electrode, or the formation of electrochemical active complex with changes of electrochemical parameters. In the case of $\mathrm{Lm}$, the formation of electro-inactive complex without a significant change of the electrochemical parameters may be considered. The competitive adsorption could have limitations, also the UV-Vis absorption spectrophotometric results proving an existing interaction between ligands and lipase, by the decrease of the absorbance of the ligands in the presence of lipase and no changes in its absorption wavelength (Figure 4).

The enzyme is more active in the presence of oxygen according to references $[40,41]$. $L r$, in the presence of the lipase and in the absence of oxygen (by introducing the sample into inert nitrogen atmosphere before the CV recording) presents a diminished of the anodic peak current, depending on the scan rate of the potential applied (results not shown). In the presence of oxygen, an evident anodic peak was observed when $0.25 \mathrm{mg} \mathrm{mL}^{-1}$ lipase was added, which disappeared in deoxygenated Lr electrolyte, confirming an inhibition of the enzyme activity (Figure 6).

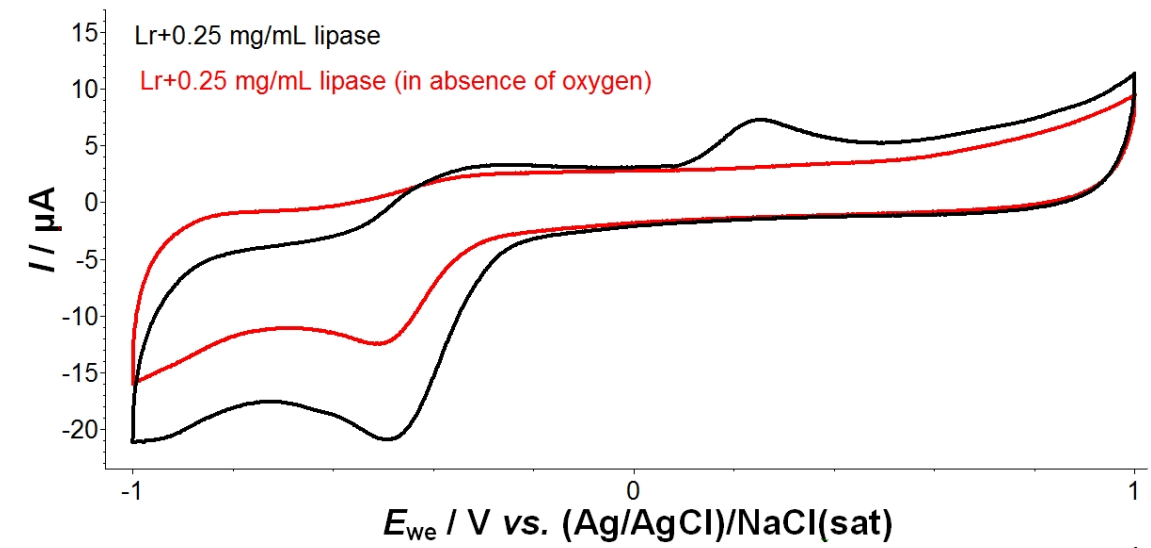

Figure 6. CVs recorded of $\mathrm{Lr}$ in $0.1 \mathrm{M} \mathrm{KNO}_{3}$ and in the presence of $0.25 \mathrm{mg} \mathrm{mL}^{-1}$ lipase with and without oxygen; $\mathrm{E} / \mathrm{V}$ vs. $\mathrm{Ag} / \mathrm{AgCl}, 0.5 \mathrm{~V} \mathrm{~s}^{-1}$ 


\section{Effect of the scan rate}

CVs were recorded at various scan rates to know variation with the lipase added which inform what type of electrochemical process is occurring the electrode surface. The lipase interaction at room temperature with the pyridinium ligands is intensively affected by the scan rate of the potential applied. CVs have shown change of waves for both ligands when the scan rate was changed from $0.02 \mathrm{~V} \mathrm{~s}^{-1}$ to $0.5 \mathrm{~V} \mathrm{~s}^{-1}$, but the discussions are made from $0.2 \mathrm{~V} \mathrm{~s}^{-1}$. Figure 7 shows $\mathrm{CVs}$ of the pyridinium ligands in the absence and in the presence of $0.25 \mathrm{mg} \mathrm{mL}^{-1}$ lipase $(\mathrm{pH} \mathrm{7.0)}$ at different scan rates. An increase of $I_{\mathrm{a}}$ is obtained for $\mathrm{Lr}$ from $2.77 \mu \mathrm{A}\left(\right.$ at $0.2 \mathrm{~V} \mathrm{~s}^{-1}$ ) to $6.3 \mu \mathrm{A}$ (at $0.5 \mathrm{~V} \mathrm{~s}^{-1}$ ) and also a slight shift of the potential from $E_{1}$ of $0.22 \mathrm{~V}$ to $E_{2}$ of $0.28 \mathrm{~V} \mathrm{vs}$. $\mathrm{Ag} / \mathrm{AgCl}$. In the same time, $\mathrm{Lm}$ does not indicate an evident anodic peak observed in the oxidation region but a slight increase of $l_{\mathrm{a}}$ with the scan rate of the potential applied was observed. The current peak increased with the increase of the scan rate and the relationship of the current oxidative peak against the scan rate in the range of $0.02-0.5 \mathrm{~V} \mathrm{~s}^{-1}$ was plotted (results not shown).

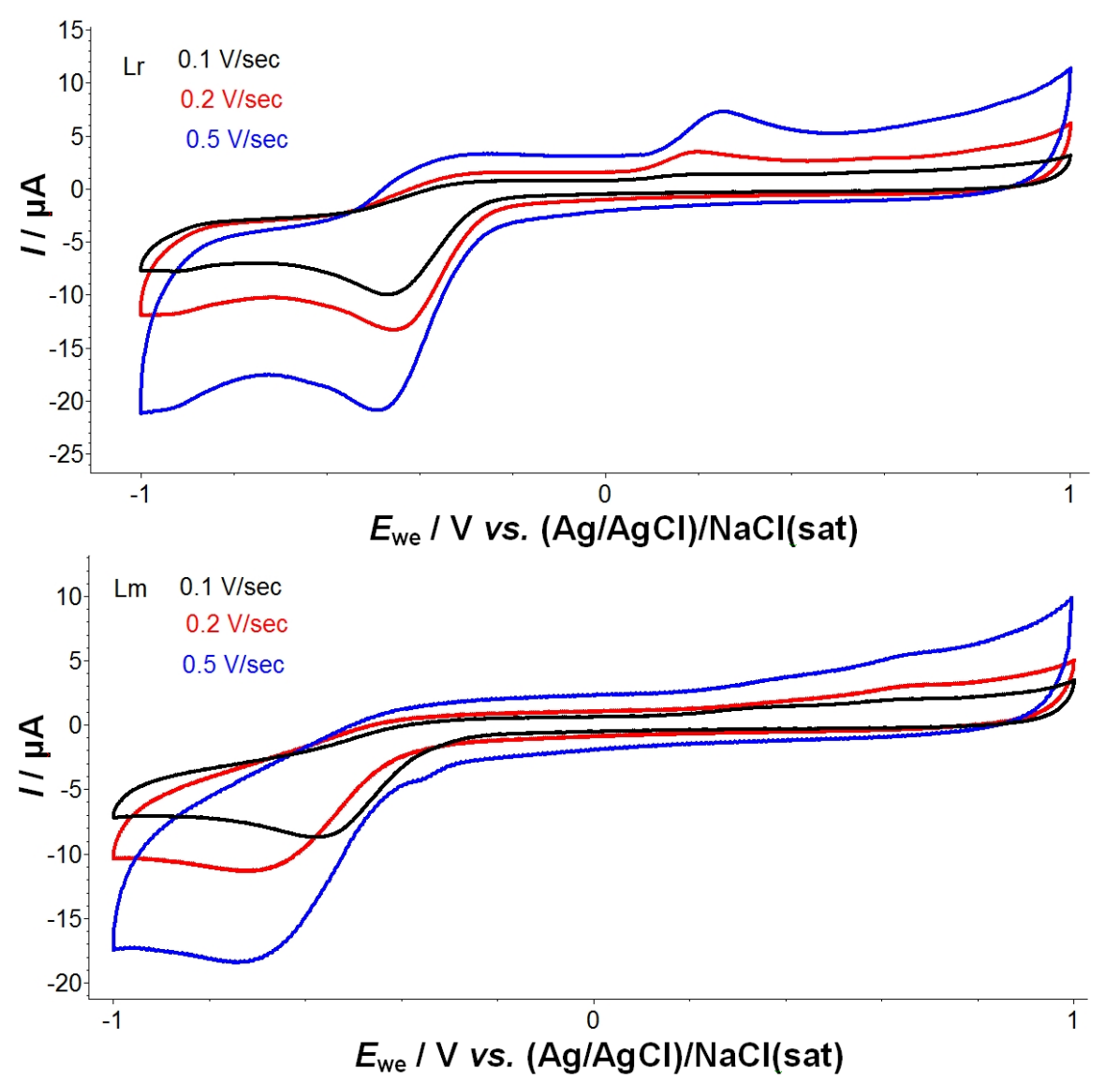

Figure 7. CVs recorded of the $L \mathrm{r}$ and $\mathrm{Lm}$ in the presence of $0.25 \mathrm{mg} \mathrm{mL}^{-1}$ of lipase at different scan rate, $\mathrm{E} / \mathrm{V}$ vs. $\mathrm{Ag} / \mathrm{AgCl}$

Figure 8 shows CVs of both ligands in the presence of $0.50 \mathrm{mg} \mathrm{mL}^{-1}$ enzyme $(\mathrm{pH} 7.0)$ at the scan rate of $0.5 \mathrm{~V} \mathrm{~s}^{-1}$. A distinct anodic peak is obtained as an effect of an intensive oxidation-reduction process, more evident for $\operatorname{Lr}($ at $+0.25 \mathrm{~V}$ ) than $\mathrm{Lm}$. The electrochemical behaviour of ligands is different, lipase showing a positively catalytic effect on $\mathrm{Lr}$ in comparison with $\mathrm{Lm}$. This catalytic activity of lipase is mainly due to the absence of the ethylenic bridge from the structure of Lr. The enzymatic activity of lipase is dependent on the substrate structure. The $l_{\mathrm{a}}$ value for $\mathrm{Lr}$ is higher than $l_{\mathrm{a}}$ of $\operatorname{Lm}\left(\Delta l_{\mathrm{a}}=45 \mu \mathrm{A}\right)$, which could be explained by a more rapid electron transfer process for $\mathrm{Lr}$, as a result of the favourable its structural arrangement, comparative with $\mathrm{Lm}$. The presence of the mobile ethylenic group marks the changes in the electrochemical performances of the $\mathrm{Lm}$. 


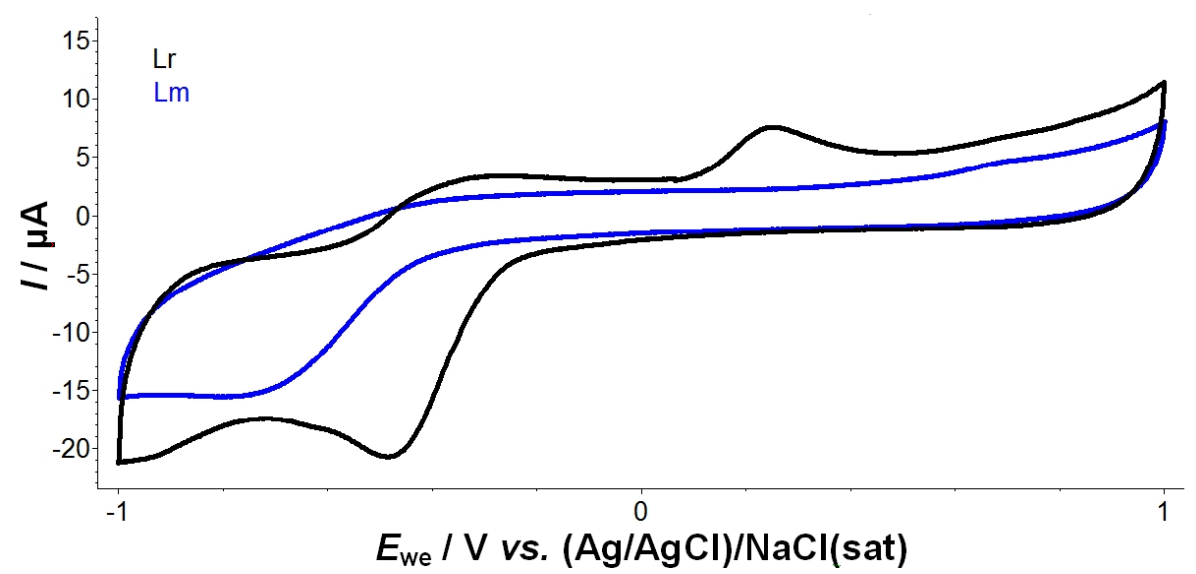

Figure 8. CVs recorded of the $L r$ and $L m$ in the presence of $0.50 \mathrm{mg} \mathrm{mL}^{-1}$ of lipase;

$\mathrm{E} / \mathrm{V}$ vs. $\mathrm{Ag} / \mathrm{AgCl}, 0.5 \mathrm{VmV} \mathrm{s}^{-1}$

No reduction wave was observed in the presence of phenacyl bromide, the precursor of pyridinium ligands, and respectively on the ethyl propiolate (synthon in cycloaddition reaction) in presence or absence of lipase. The lipase interaction with the precursors is not observed (Figure 9). CVs recorded only the effect of the diffusion process on the carbon electrode. These results demonstrated that the two pyridinium ligands with different structures than the precursor phenacyl bromide have shown an electro-oxidation behaviour and an interaction with lipase was observed (Figures 5-8).

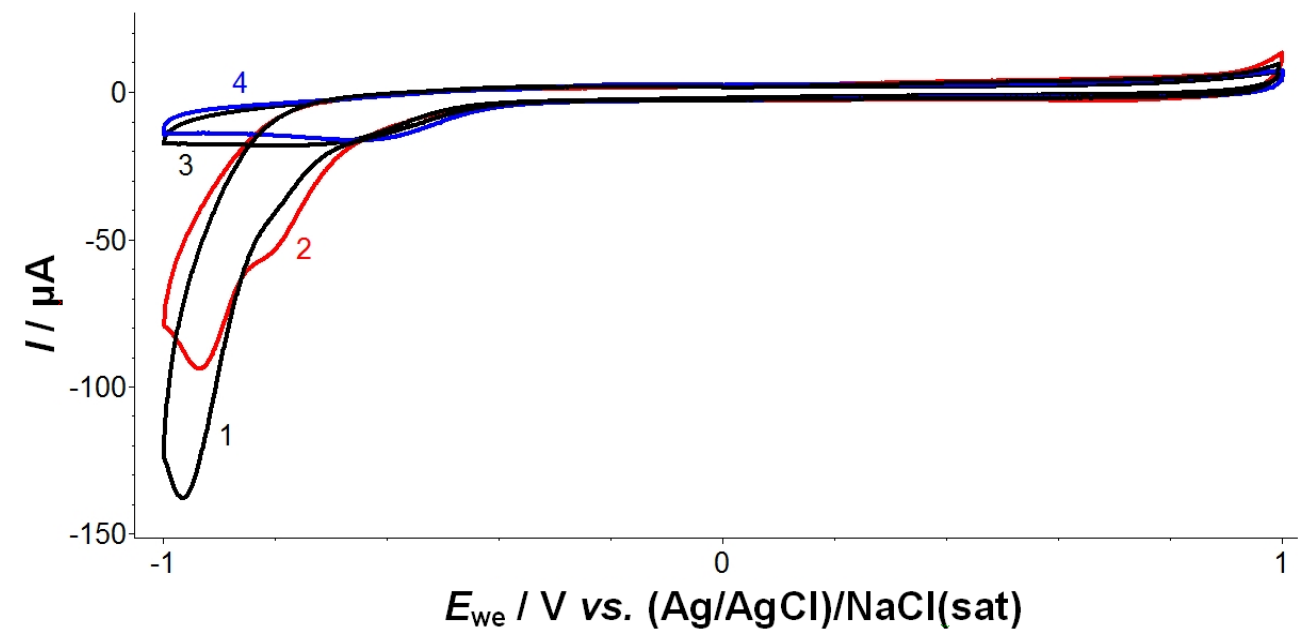

Figure 9. CVs recorded of phenacyl bromide in the absence and in presence of lipase $0.25 \mathrm{mg} \mathrm{mL}^{-1}$ (1, respectively 2); ethyl propiolate in the absence and in presence of lipase $0.25 \mathrm{mg} \mathrm{mL}^{-1}$ (3, respectively 4); $\mathrm{E} / \mathrm{Vvs}$. $\mathrm{Ag} / \mathrm{AgCl}, 0.5 \mathrm{~V} \mathrm{~s}^{-1}$

\section{Structural characterization}

The lipase was analyzed before and after interaction with the ligands to observe the morphology and structural changes of enzyme. The lipase (white powder) became violet-red after 1 day in contact with $\mathrm{Lr}$ and weak yellow after the contact with $\mathrm{Lm}$. The recuperated lipase from the contact with ligands after the CV measurements was filtered and dried in air at room temperature. This result has shown that the competitive absorption between ligand molecule and lipase can exist. The SEM images and elemental analysis (EDX) was performed when lipase was placed on carbon-coated-copper. SEM images show a modification in the structure of lipase before of the experiment and after the interaction with the ligands, in the presence or in the absence of oxygen (Figure 10). 
The particle size of lipase (Figure 10a) changes significantly, being reduced in comparison with the particle size after the interaction of enzyme with the Lr electrolyte, when the nitrogen was purged before the electrochemical analysis (Figure 10c). Anyway, the chemical analysis indicated almost same concentration of the enzyme, carbon $95.89 \mathrm{wt} \%$ versus $95.44 \mathrm{wt} \%$ and respectively oxygen $4.11 \mathrm{wt} \%$ versus $4.56 \mathrm{wt} \%$, so enzyme was present in both systems. The reduction of carbon at $88.2 \mathrm{wt} \%$ and oxygen at $1.5 \mathrm{wt} \%$, boron (10.18 wt \%), also $\mathrm{Na}$ and $\mathrm{Mg}$ in small content with a strengthening role in the cell is evident a result of a contact of lipase with Lr in the presence of oxygen (Figure 10b). The results have also shown an interaction of lipase with ligands with the formation of an enzymatic complex.
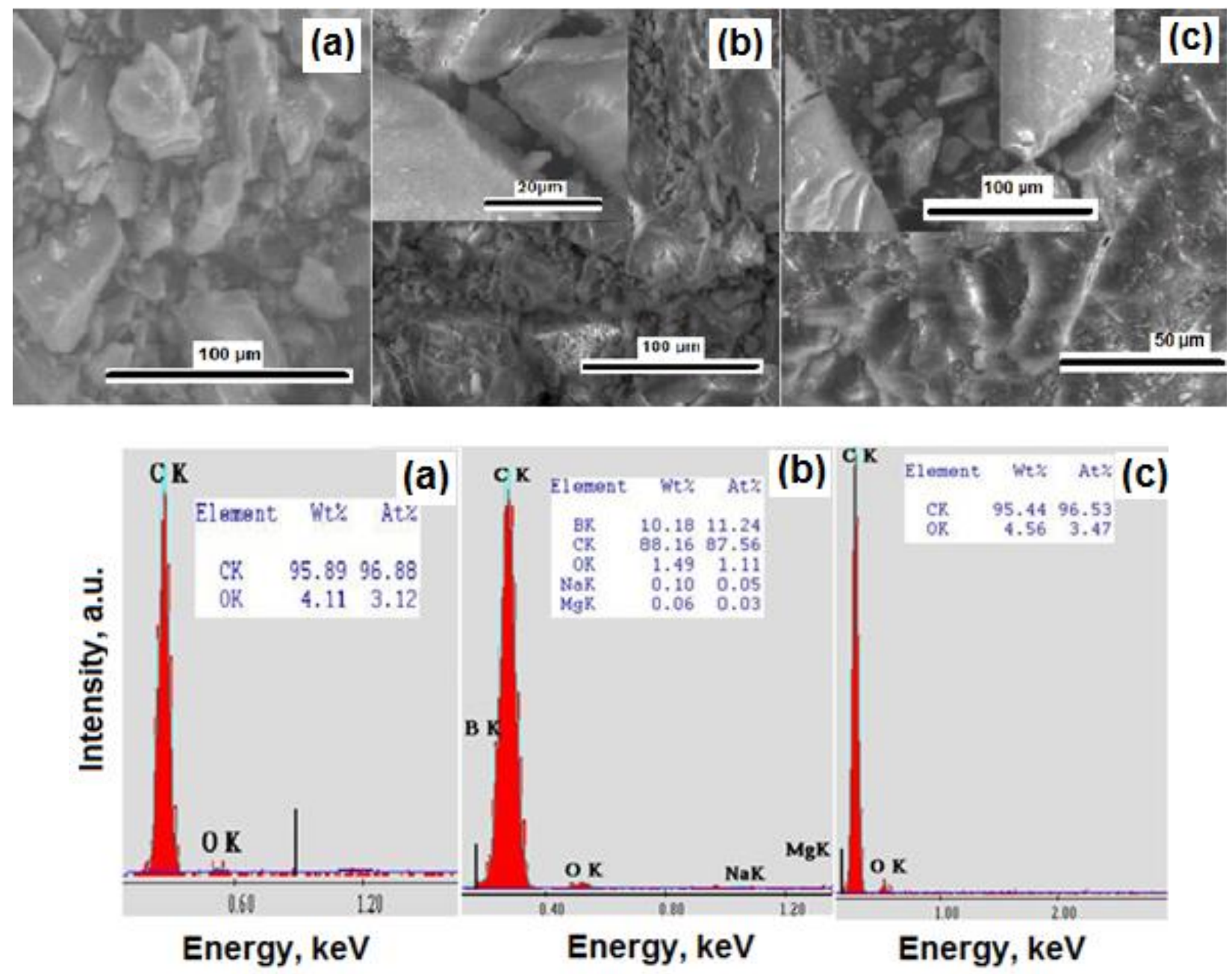

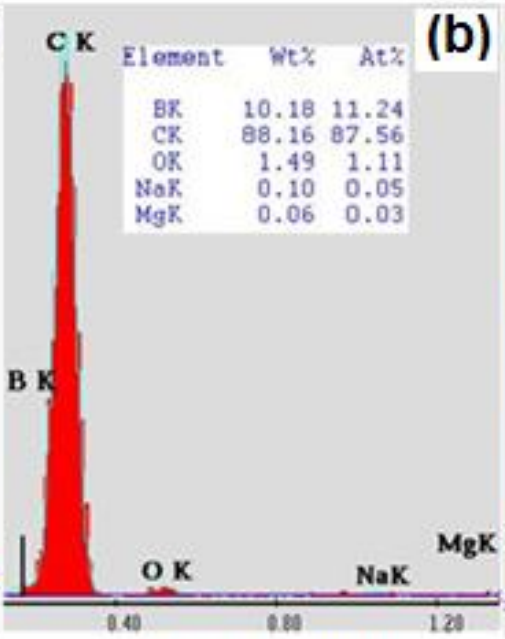

Energy, keV

(b)

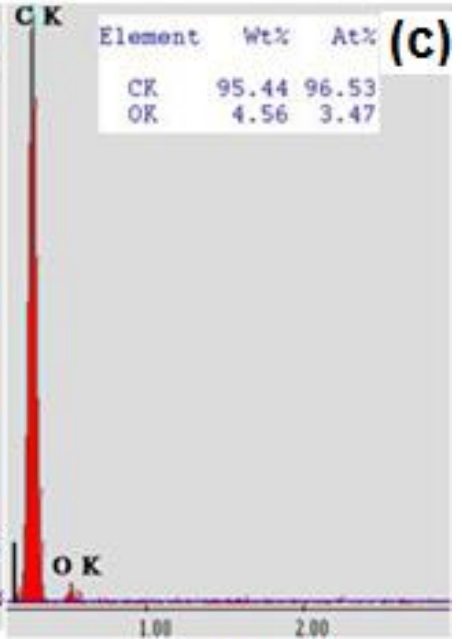

Energy, keV

Figure 10. SEM images and EDX analysis of $L$ - enzyme (a); lipase interaction with $L r$ in the presence of oxygen (b) and without oxygen (c)

\section{Suggested mechanism}

The voltammetric method is used for the investigation of the interaction of the ligands with lipase [42-44]. The decrease of the reductive current's peak of the reaction solution when lipase was added suggests the decrease of free ligands concentration (Figures 5-8). Based on the decrease of current's peak when the enzyme increasing, the electrochemical method could estimate the determination of lipase or different kinds of proteins according to references [42-44].

The specific adsorption of ligand on quasireversible reduction wave at $-0.4 \mathrm{Vvs} . \mathrm{Ag} / \mathrm{AgCl}$ is associated with the one electron reduction of the pure ligand. The oxidation mechanism of Lr with small lipase amount could proceed in a successive steps, as the two anodic peaks, one of lower 
intensity, could be an explanation of a secondary product, process controlled by diffusion. The formation of a single ligand-lipase complex was proposed.

In the acidic solution, at pH $6.5-7.0$ the lipase are positively charged, while the ligands species are zwitterion structures and an electrochemical quasireversible process is provided. Initially the ligands, possibly negatively charged, are electrostatically attracted to lipase. According to literature $[41,42]$ the composition and the equilibrium constant could be calculated based on the changes of peak current.

Our results show that both ligands follow different mechanisms their structures. The differences of electrochemical behaviour could be attributed to the structural differences between the two pyridinium ligands investigated. The chemical reaction is proposed to take place following a protonation ECE mechanism [45]. The proposed mechanism of $L r$ is the reducing in the protonated form at lower $\mathrm{pH}$ in two electronic steps. In acidic media, $\mathrm{Lr}$ was deprotonated on the radical cation formed after the first one electron transfer. Firstly, it is the reduction of ligands, noted as $\mathrm{Lr}$ $\left(\mathrm{Lr} / \mathrm{Lr}^{+-}\right)$and the second step is the role of electron carrier of pyridinium ligand $\left(\mathrm{Lr}^{+} / \mathrm{Lr}^{++}\right)[27]$. The radical intermediate subsequently undergoes $\mathrm{AH}^{-}$to the formation of a new radical on the ligand $\mathrm{Lr}^{+}$. $\mathrm{Lm}$ having the ethylene group follows sequence ECE in acidic media with the second step that from the mobile ethylene group and the deprotonation is not fast realized. Our study and suggested mechanism is useful to understand the steps of the cycloaddition reactions mechanism in which the studied compounds (pyridinium ligands) could participate as synthons [9].

\section{Conclusions}

The interaction between lipase and two pyridinium ligands derived from 4,4-bipyridine in $0.1 \mathrm{M} \mathrm{KNO}_{3}$ electrolyte from initial contact and during a certain period of time has been demonstrated. The $\mathrm{pH}$ and conductivity measurements also OCP sustain a rapid ionic exchange between ligands and lipase. The stability of the ligands is influenced by the lipase content. The decrease of the absorbance from UV/Vis spectra of the both ligands in aq. electrolyte and in the presence of lipase confirms binding interactions have occurred in the reaction media. The temperature is an important factor of this interaction and an inhibition of lipase activity on ligands structure is confirmed at $40^{\circ} \mathrm{C}$.

The lipase content has substantial effects on redox properties of the electron transfer between pyridinium ligands and lipase and depends on the ligands' structure. The recorded voltammograms show a more intensive electronic transfer due to the interaction of $\mathrm{Lr}$ with lipase in comparison with Lm because of the absence of a mobile ethylenic bridge which is present in the Lm chemical structure. In the presence of oxygen, the interaction of the pyridinium ligands with the enzyme is different, taking into account the physico-chemical properties and the redox potential. This might result from the most favourable arrangement of the Lr molecular structure than $\mathrm{Lm}$, depending also on the lipase concentration.

Acknowledgements: This work was supported by a grant of the Romanian National Authority for Scientific Research, CNCS-UEFISCDI project number PN-II-ID-PCE-2011-3-0226.

\section{References}

[1] B. Furdui, R. Dinică, M. Demeunynck, I. Druță, Al. Vlahovici, Revue Roumaine de Chimie 52(7) (2007) 633-637.

[2] B. Furdui, G. Parfene, I.O. Ghinea, R. M. Dinică, G. Bahrim, M. Demeunynck, Molecules 19(8) (2014) 11572-11585. 
[3] L. Găină, I. Torje, E. Gal, A. Lupan, C. Bischin, R. Silaghi-Dumitrescu, G. Damian, P. Lönnecke, C. Cristea, L. Silaghi-Dumitrescu, Dyes and Pigments 102 (2014) 315-325.

[4] L. Sun, J. von Gersdorff, J. Sobek, H. Kurreck, Tetrahedron 51(12) (1995) 3535-3548.

[5] M. Ohno, Y. Tanaka, M. Miyamoto, T. Takeda, K. Hoshi, N. Yamada, A. Ohtake, Bioorganic \& Medicinal Chemistry 14(6) (2006) 2005-2021.

[6] R. Palin, J. K. Clark, P. Cowley, A. W. Muir, E. Pow, A. B. Prosser, R. Taylor, M. Q. Zhang, Bioorganic \& Medicinal Chemistry Letters 12(18) (2002) 2569-2572.

[7] L. Yuan, Y. Xu, X. Hu, G. Yang, Y. Wu, Journal of Molecular Catlysis A: Chemical 396 (2015) 55-60.

[8] M. A. Zolfigol, A. R. Moosavi-Zare, M. Zarei, Comptes Rendus Chimie 17(12) (2014) 12641267.

[9] R. M. Dinică, B. Furdui, I. O. Ghinea, G. Bahrim, S. Bonte, M. Demeunynck, Marine Drugs 11(2) (2013) 431-439.

[10] A. Vlahovici, I. Druță, M. Andrei, M. Cotlet, R. Dinică, Journal of luminescence 82(2) (1999) 155-162.

[11] M. Kapoor, M. N. Gupta, Process Biochemistry 47 (2012) 555-569.

[12] A. M. Bezborodov, N. A. Zagustina, Applied Biochemistry and Microbiology 50(4) (2014) 313-337.

[13] T. Fuse, G. Oda, K. Arai. K. Takamura, F. Kusu, Electrochemica Acta 45(18) (2000) 29332937.

[14] G. W. Huisman, S. J. Collier, Current Opinion in Chemical Biology 17 (2013) 284-292.

[15] M. B. Ansorge-Schumacher, O. Thum, Chemical Society Reviews 15 (2013) 6475-6490.

[16] A. Salihu, Md. Z. Alam, M. I. AbdulKarim, H. M. Salleh, Resources, Conservation and Recycling 58 (2012) 36-44.

[17] P. Ittrat, T. Chacho, J. Pholprayoon, N. Suttiwarayanon, J. Charoenpanich, Biocatalysis and Agricultural Biotechnology 3 (2014) 77-82.

[18] V. Gotor-Fernández, E. Busto, V. Gotor, Advanced Synthesis \& Catalysis 348 (7-8) (2006) 797-812.

[19] M. Stoycheva, G. Montero, R. Zlatev, J. A. Leon, V. Gochev, Current Analytical Chemistry 8 (2012) 400-407.

[20] E. N. Vulfson, Industrial application of lipases. In lipases: Their structure, biochemistry and application, University Press, Cambridge, 1994, p. 271.

[21] A. K. Sanap, G. S. Shankarling, Catalysis Communications 49 (2014) 58-62.

[22] B. Zou, C. Song, X. Xu, J. Xia, S. Huo, F. Cui, Applied Surface Science 311 (2014) 62-67.

[23] S. Yamaguchi, M. Tanha, A. Hult, T. Okuda, H. Ohara, S. Kobayashi, Polymer Journal 46 (2014) 2-13.

[24] C. Wu, X. Liu, Y. Li, X. Du, X. Wang, P. Xu, Biosensors and Bioelectronics 53 (2014) 26-30.

[25] R. Sharma, Y. Chisti, U.C. Banerjee, Biotechnology Advances 19(8) (2001) 627-662.

[26] B. Furdui, R. M. Dinica, A. Tabacaru, C. Pettinari, Tetrahedron 68 (2012) 6164-6168.

[27] A. Carac, R. Boscencu, R. M. Dinica, G. Carac, Studia UBB Chemia LX(3) (2015) 99-109.

[28] R. Dinică, B. Furdui, G. Bahrim, M. Demeunynck, Revue Roumaine de Chimie 53(1) (2008) 21-24.

[29] C. C. Akoh, D. B. Min, Food Lipids: Chemistry, Nutrition, and Biotechnology, CRC Press, 2002, p. 866.

[30] L. Liang, R. Zhang, N. S. Weng, J. Zhao, C. Liu, Inorganic Chemistry Communications 64 (2016) 56-58.

[31] R. A. Alberty, Biophysical Chemistry 125(2-3) (2007) 328-333.

[32] R. M. Daniel, M. J. Danson, Trends Biochemistry Science 35(10) (2010) 584-591. 
[33] S. Menoncin, N. M. Domingues, D. M. Guimarães Freire, G. Toniazzo, R. L. Cansian, J. V. Oliveira, M. Di Luccio, D. de Oliveira, H. Treichel, Food Bioprocess Technology 3 (2010) 537-544.

[34] W. M. Linfield, D. J. O'Brien, S. Sereta, R. A. Barauskas, Journal of the American Oil Chemists Society 61(6) (1984) 1067-1071.

[35] K. Shimazu, M. Yanagida, K. Uosaki, Journal of Electroanalytical Chemistry 350 (1993) 321327.

[36] A. Czardybon, J. Zak, M. Lapkowski, Polish Journal of Chemistry 78(9) (2004) 1533-1541.

[37] Y. Jiang, C. Guo, H. Xia, I. Mahmood, C. Liu, H. Liu, Journal of Molecular Catalysis B: Enzymatic 58 (2009) 103-109.

[38] M. Tudorache, A. Nae, S.Coman, V. I. Parvulescu, RSC Advances 3 (2013) 4052-4058.

[39] A. M. O. Brett, M. E. Ghica, Electroanalysis 15 (2003) 1745-1750.

[40] S. Kim, S. E. Yun, C. Kang, Journal of Electroanalytical Chemistry 462 (1999) 153-159.

[41] N. F. Ferreyra, S. A. Dassie, V. M. Solis, Journal of Electroanalytical Chemistry 482 (2000) 126-132.

[42] W. Sun, K. Jiao, X. Wang, L. Lu, Journal of Electroanalytical Chemistry 17(2) (2005) 162-168.

[43] Y. Q. Li, Y. J. Guo, X. F. Li, J. H. Pan, Talanta 71(1) 2007 123-128.

[44] F. Hasan, A. A. Shah, A. Hameed, Biotechnology Advances 27(6) (2009) 782-798.

[45] V. T. Kumar, R. L. Burke, Analytical Chemistry 65(18) (1993) 2428-2436.

(C) 2016 by the authors; licensee IAPC, Zagreb, Croatia. This article is an open-access article distributed under the terms and conditions of the Creative Commons Attribution license (http://creativecommons.org/licenses/by/4.0/) 